\title{
Nodular fasciitis on the zygomatic region: a rare presentation*
}

\author{
Fasciíte nodular na região zigomática: uma apresentação rara
}

\author{
Ilner de Souza e Souza ${ }^{1}$ \\ Roberto Bezerra Vieira ${ }^{4}$
}

\author{
Mayra Carriijo Rochael ${ }^{2}$ \\ Janaina Silva Tirapelle Vieira ${ }^{5}$
}

\author{
Rogério Estevam Farias ${ }^{3}$ \\ Nathalia Campos Schimidt ${ }^{6}$
}

\begin{abstract}
Nodular fasciitis is a benign tumor, resulting from reactive proliferation composed of fibroblastic/myofibroblastic cells. Due to its rapid growth and high cellularity it may be mistaken for sarcoma. Despite the possibility of spontaneous regression, excision is the treatment of choice. A 24-year-old female patient presented with a nodule on the zygomatic region with 3 months of evolution. Excisional biopsy was performed. Histopathological examination associated with immunohistochemical markers HHF35, AML and Ki-67 allowed diagnostic confirmation. The main relevance of the case presented is its rare location, suggesting its inclusion among the differential diagnoses of tumor lesions on the face.
\end{abstract}

Keywords: Fasciitis; Immunohistochemistry; Solitary fibrous tumors

Resumo: A fasciíte nodular é um tumor benigno, decorrente da proliferação reativa de células fibroblásticas ou miofibroblásticas. Pode ser confundida com os sarcomas, devido a seu rápido crescimento e rica celularidade. Apesar da possibilidade da involução espontânea, a excisão é o tratamento de escolha. É apresentada uma paciente de 24 anos, com um nódulo de 3 meses de evolução na região zigomática. Foi realizada biópsia excisional. O exame histopatológico associado à imuno-histoquímica com os marcadores HHF35, AML e Ki-67 permitiram a confirmação diagnóstica. A principal relevância do caso apresentado é sua rara localização, sugerindo a sua inclusão entre os diagnósticos diferenciais das lesões tumorais na face.

Palavras-chave: Fasciite; Imunoistoquímica; Tumores fibrosos solitários

\section{INTRODUCTION}

Nodular fasciitis (NF) is considered a benign tumor deriving from reactive proliferation of fibroblast and myofibroblast cells that affect hypodermis, muscles and fasciae. ${ }^{1,2}$ Its etiology is still uncertain although reports exist of previous local traumas in 10$15 \%$ of the cases. ${ }^{3}$

NF was described in 1955 by Konwaler et al. It was designated pseudosarcomatous fasciitis or infiltrating fasciitis due to its great similarity with sarcoma. ${ }^{4}$

In 1966 Mehregan et al. suggested the simpler description 'nodular fasciitis' based on the analysis of clinical, histopathological and epidemiological characteristics in 17 patients. $^{2}$

Dermatological examination reveals a generally single nodule of fast growth, measuring from one to five centimeters in diameter which is sometimes painful under pressure. ${ }^{5}$ Upper extremities and trunk are predominantly affected, with rare involvement of the head and neck. ${ }^{6}$

Some presentations may be mistaken for sarcomas due to rapid growth, rich cellularity and high mitotic activity. For this reason it is important to distinguish

Received on 22.01.2013.

Approved by the Advisory Board and accepted for publication on 08.02.2013.

* Work performed at the Dapele Medical Center - Manaus (AM), Brazil.

Conflict of interest: None

Financial funding: None

Master in Dermatology - Chief of Dermatology Department of the DaPele Medical Center - Manaus (AM), Brazil.

PhD in Pathology - Associate Professor, Department of Pathology, Universidade Federal Fluminense (UFF) - Niterói (RJ), Brazil.

PhD in Pathology - Associate Professor, Department of Morphology, Juiz de Fora Federal University (UFJF) Minas Gerais (MG), Brazil.

Specialist in Plastic Surgery - Plastic Surgeon of the DaPele Medical Center - Manaus (AM), Brazil.

Post-graduate degree in Dermatology - Assistant Physician of the DaPele Medical Center - Manaus (AM), Brazil.

Graduate in Medicine - Assistant Physician of the DaPele Medical Center - Manaus (AM), Brazil. 
the condition from a malignant neoplastic disease. ${ }^{4}$ Although spontaneous remission may occur, excision is the treatment of choice, with rare recurrences. ${ }^{7}$

\section{CASE REPORT}

A 24-year-old, brown-skinned female presented with a nodule on the right zygomatic region, of progressive growth for 3 months, without previous traumas, inflammatory processes or local symptoms.

Physical examination revealed a nodule measuring around one centimeter in diameter, of firm consistency, regular shape and movable in relation to the skin and deep tissues. No lymphadenomegaly was observed. Patient was in good health, with no evidence of systemic involvement. Main diagnostic hypotheses were epidermoid cyst, trichilemmal cyst and pilomatrixoma.

Excisional biopsy was carried out and macroscopically pointed to a irregularly-shaped white-yellow mass $1.0 \times 0.6 \mathrm{~cm}$ in diameter (Figure 1).

Histopathological examination showed a nonencapsulated proliferation of mesenchymal tissue with irregular edges and spiky contours, extending from the dermis to hypodermis. The lesion consisted of thin spindle cells forming bundles in several directions, interposed by thick and hyaline collagen fibers, without cell atypias. Areas of myxoid aspect, extravasation of erythrocytes and discrete lymphoid infiltrate were also observed. (Figure 2)

Immunohistochemical studies were performed with antibodies to CD34, desmin, muscle-specific actin (HHF35), smooth muscle actin (SMA) and Ki-67. The lesion demonstrated immunopositivity for HHF35 and SMA and was slightly positive for Ki-67 (Figures 3 to 5).

Clinical, anatomopathological and immunohistochemical findings taken together led to the conclusion that the excised lesion was nodular fasciitis.

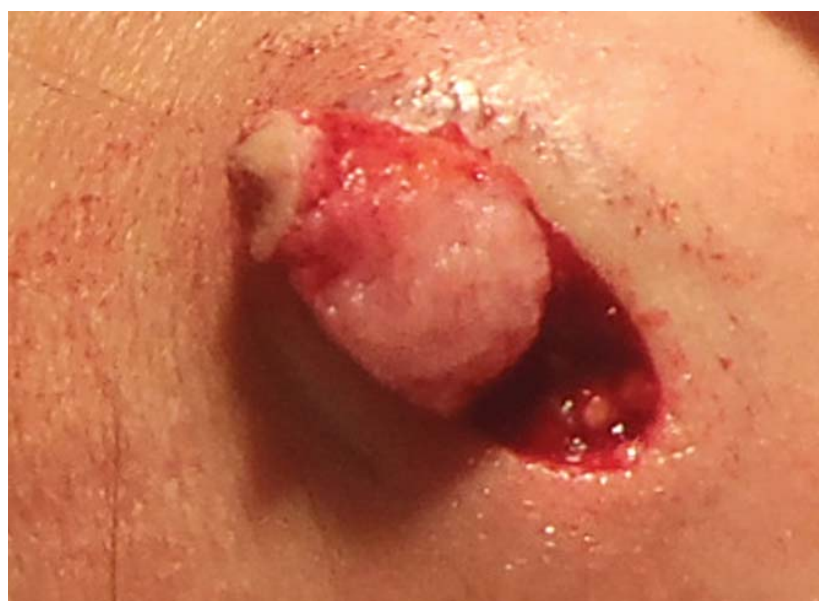

FIGURE 1: Transoperatory biopsy

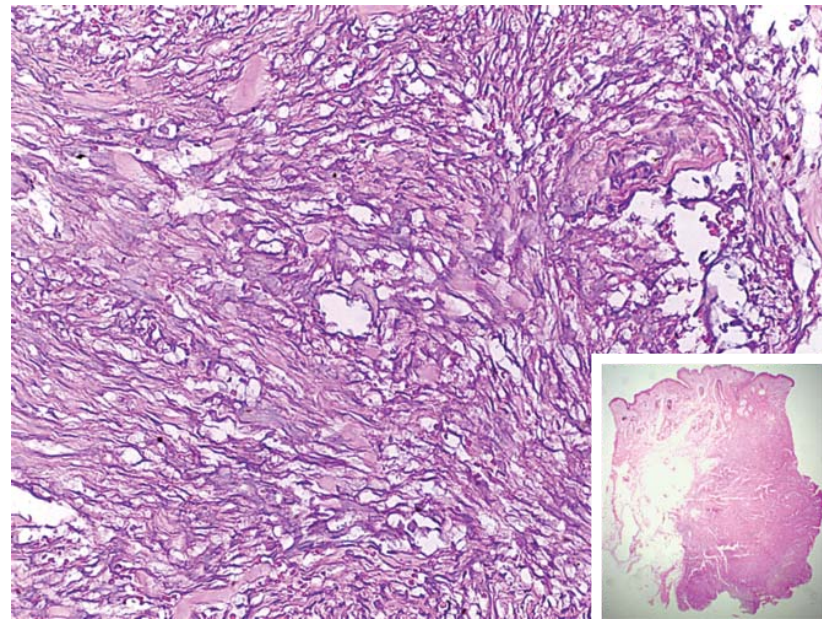

FIGURE 2: Proliferation of spindle cells intermingled with vessels, areas of myxoid appearance and extravasation of red blood cells (HE, 200x). In the detail, note the deep location of the lesion (HE, 10x)

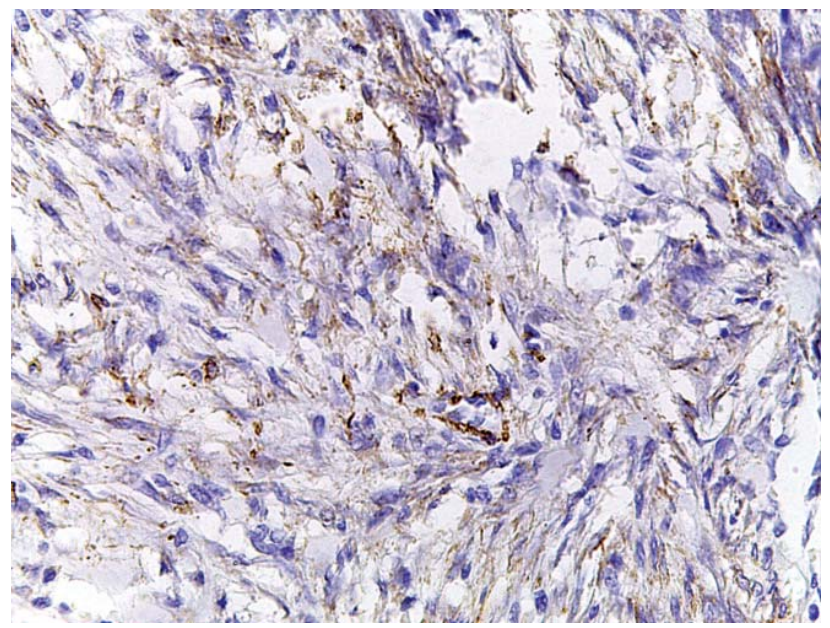

FIgURe 3: Positivity for anti-smooth muscle actin

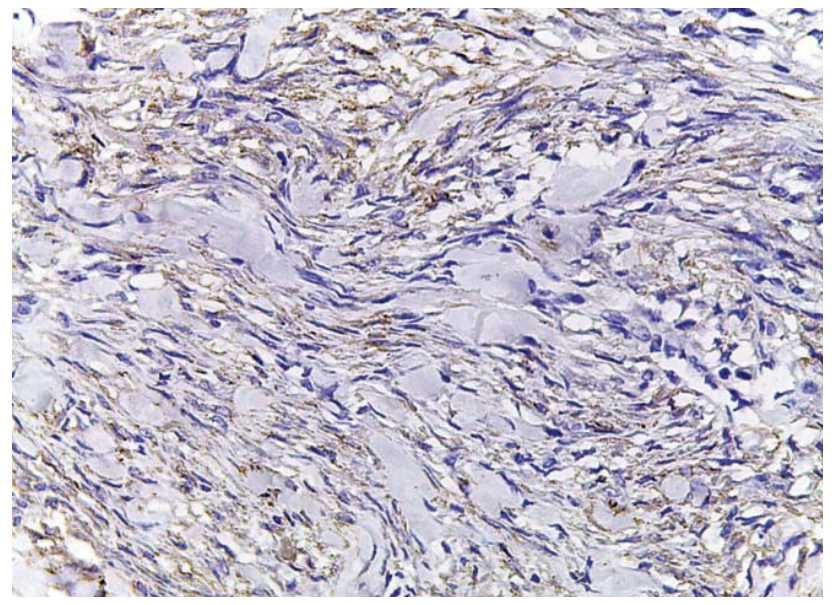

FIGURE 4: Positivity for anti-HHF 35 (muscle specific) 


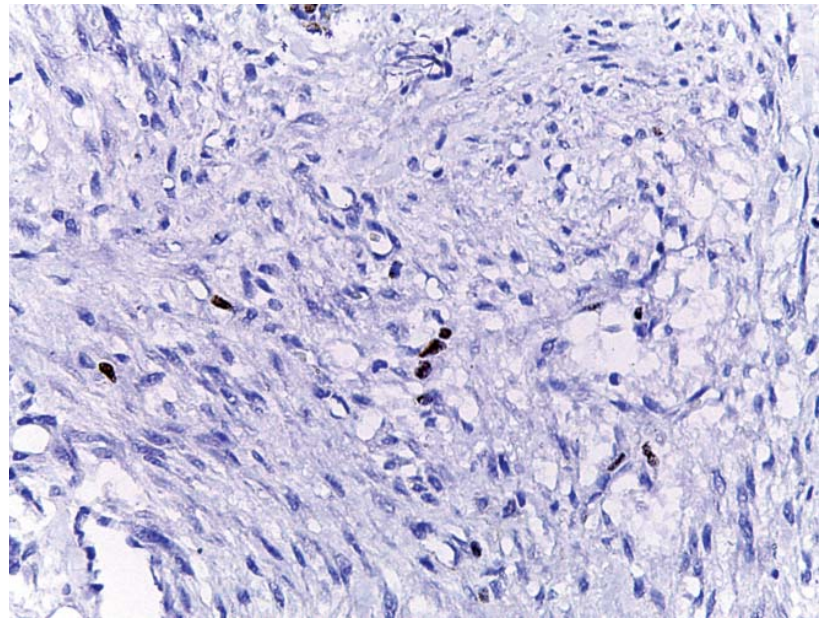

FIGURE 5: Small number of ki-67-positive cell nuclei

\section{DISCUSSION}

NF is a fibrous lesion studied along with tumors and fibrous proliferations, such as myositis ossificans, hyalinizing leiomyoma, fibrous histiocytoma, epithelioid fibrosarcoma, clear cell sarcoma of tendons and aponeuroses, small cell osteosarcoma, alveolar rhabdomyosarcoma and dermatofibrosarcoma protuberans. ${ }^{8}$

It occurs at all ages, with greater frequency between the third to fifth decades. The upper extremities are the mostly affected location, responsible for $39 \%$ to $54 \%$ of cases, with the volar region of the forearm being the most common location. The trunk is affected in $15 \%$ to $20 \%$ of patients. $16 \%-18 \%$ of the reports describe involvement of the lower extremities. While face and neck account for only $7 \%-20 \%$ of cases, they are nevertheless the most common location among children. ${ }^{4}$

According to a retrospective study of 30 cases of $\mathrm{NF}$ in cephalic and cervical regions, no reference is made to involvement of the zygomatic arch, although four of the lesions studied presented on the cheeks. ${ }^{1}$ Less commonly affected areas include the skull, eyes, parotid glands, conjunctiva and mouth. ${ }^{1}$

Spontaneous remission that occurred in some cases and the frequent location on zones of bony prominence may support the hypothesis of previous trauma as a triggering factor for $\mathrm{NF}^{2}$ However, in the reported case there was no history of trauma.

Due to its fast growth and the presence of mitosis, differential diagnosis with malignant neoplasms is essential in order to avoid unnecessary surgical procedures. ${ }^{6}$

When dealing with tumors located at the zygomatic region, clinical suspicion of NF is exceptional.
The most common clinical diagnoses are: dermatofibroma, lipoma, fibrolipoma, fibrous hematoma and lymphadenomegaly. ${ }^{4}$ Fibrosarcoma is the malignant neoplasm leading most often to misdiagnosis. ${ }^{4}$ It is also important to differentiate NF from lymph node metastasis, papillary carcinoma, Burkitt's lymphoma, pleomorphic adenoma and vascular proliferative process. $^{6}$

Although cysts are not part of differential diagnosis of NF in the literature, the main hypothesis for the aforementioned case was epidermoid cyst, the most common cutaneous cyst, due to its characteristics: rounded tumor, firm consistency and subcutaneous location. ${ }^{7}$

Immunohistochemical analysis is essential for diagnostic confirmation of NF featuring reactivity for smooth muscle actin (SMA) and muscle-specific actin (HHF35). ${ }^{1}$ CD 34 may be used to differentiate NF from dermatofibrosarcoma protuberans. Desmin may rarely be expressed in NF, being a characteristic of leiomyoma and leiomyosarcoma. ${ }^{9}$

Employing Ki-67 allows the amount of cell proliferation to be evaluated and ensures the possibility of prognostic investigation of neoplasias..$^{10}$

In the case reported here we observed immunopositivity for SMA, HHF35 and Ki-67, as well as immunonegativity for CD34 and desmin. Few cores were marked by the Ki-67 antibody, showing a low amount of cell proliferation, which differed from the cases found in the literature.

Surgical procedure is preferred for NF, with a recurrence rate of $1 \%$ to $10 \%$, probably due to incomplete excision. ${ }^{2}$

Oral or intralesional corticotherapy may also be used. The main criticism against this choice is the lack of histopathological confirmation in the reported cases.

In the present case, the chosen conduct was excisional biopsy. There was no recurrence within six months of follow-up.

The main relevance of our case was the uncommon location of the lesion, which suggests the inclusion of NF amidst the differential diagnoses of tumor lesions on the face. Excisional biopsy would appear to be the best treatment choice in this topography. Histopathological examination associated to immunohistochemistry is indispensable for diagnostic conclusion, thus avoiding mutilation procedures when the lesion is wrongly considered to be a malignant mesenchymal neoplasm. Low positivity of the cell proliferation marker could indicate possible spontaneous involution. 


\section{REFERENCES}

1. Weinreb I, Shaw AJ, Perez-Ordoñez B, Goldblum JR, Rubin BP. Nodular fasciitis of the head and neck region: a clinicopathologic description in a series of 30 cases. J Cutan Pathol. 2009;36:1168-73.

2. Almeida F, Picón M, Pezzi M, Sánchez-Jaúregui E, Carrillo R, Martínez-Lage JL. Nodular fascitis of the maxillofacial region. Two case reports and a review of the literature. Rev Esp Cir Oral y Maxilofac. 2007;29:43-7.

3. Morales DV, Cabrales ES. Nodular fasciitis present in facial area in children. Rev Cuba Estomatol. 2009;46:78-87.

4. Vyas T, Bullock MJ, Hart RD, Trites JR, Taylor SM. Nodular fasciitis of the zygoma: A case report. Can J Plast Surg. 2008;16:241-3.

5. Garrido RN, Vieira W. Fasciite Nodular Pseudo-Sarcomatosa. An Bras Dermatol. 1970;45:305-12.

6. Borumandi F, Cascarini L, Mallawaarachchi R, Sandison A. The chameleon in the neck: Nodular fasciitis mimicking malignant neck mass of unknown primary. Int $J$ Surg Case Rep. 2012;3:501-3.

7. Fitzpatrick TB. Tratado de Dermatologia. 7th. ed. Rio de Janeiro: Revinter; 2010.

8. Borba PP, Fiod NJ, Gouveia GC, Nascimento MF, Rezende JF. Fibrossarcoma epitelióide esclerosante: relato de caso. Rev Bras Cancerol. 2003;49:221-5.

9. Fleury LFF Jr, Sanches JA Jr. Sarcomas cutâneos primários. An Bras Dermatol. 2006;81:207-21.

10. Vieira FD, Guimarães MAM, Aarestrup FM, Vieira BJ. Evaluation of proliferative index by the expression of Ki-67 in samples of squamous cell carcinoma of the oral mucosa and correlation with histology studies. Odontol Clín Cient. 2009;8:359-63.
MAILING ADDRESS:

Ilner de Souza e Souza

Rua Maceió, 467- Nossa Senhora das Graças

69057-010 - Manaus - AM

Brazil

E-mail:drilner@dapeledermatologia.com.br

How to cite this article: Souza-e-Souza I, Rochael MC, Farias RE, Vieira RB, Vieira JST, Schimidt NC. Nodular fasciitis on the zygomatic region: A rare presentation. An Bras Dermatol. 2013;88(6 Suppl 1):S89-92. 